\title{
A new species of the freshwater tanaidacean genus Pseudohalmyrapseudes (Crustacea: Tanaidacea: Parapseudidae) from Sulawesi
}

\author{
Roger N. Bamber \\ The Natural History Museum, Cromwell Road, London SW7 5BD, United Kingdom. \\ E-mail: R.Bamber@nhm.ac.uk

\begin{abstract}
A new species of the freshwater apseudomorph tanaidacean genus Psetudohalmyrapsendes is described from Dadeleang Cave in Sulawesi: Psetdohalmyrapseudes limnaci. The range of morphological differences between the three known species of the genus is tabulated. Allopatric speciation between taxa inevitably isolated owing to their freshwater habitat is discussed as are the links with the closely-related genus Halmyrapsudes.
\end{abstract}

\section{INTRODUCTION}

Freshwater tanaidaceans are rare (see Larsen and Hansknecht 2004, for a brief review of the relevant literature). The most widely recorded is the pantropical-subtropical tanaid Sinelobus stanfordi (Richardson 1901), a euryokous species recorded from estuaries, from reduced salinities in mangrove systems, and in fully freshwater habitats, including at an altitude of $823 \mathrm{~m}$ [sic] on St Helena (Monod 1977; see also Stephensen 1936; Gardiner 1975). A further freshwater tanaidomorph, recorded only once, is the nototanaid Androtanais beebei (Van Name 1925), found in a catfish stomach in British Guiana (Van Name 1925). Some other estuarine species may extend into freshwater temporarily, most notably the leptocheliid Heterotanais oerstedi (Kroyer 1842), which has been recorded from sites where salinities drop as low as $0 \%$ at low tide or seasonally.

Apseudomorph tanaidaceans from reduced salinity waters are also rare. The genus Halmyrapseudes Bãcescu and Gutu 1974 is known from seven species, all from brackish waters (as low as $10 \%$ where salinity was recorded: see Bamber et al. 2002). The only genus of apseudomorph tanaidacean recorded from freshwater habitats is the closely-related Pseudohalmyrapseudes, erected by Larsen and Hansknecht (2004) for their new species $P$. aquadulcis from a freshwater spring in Northern Territory, Australia (near Darwin), and to which they moved Apseudes mussauensis Shiino 1965; P. mussauensis was recorded from a "brackish" lake on Mussau Island, Bismarck Archipelago (Shiino 1965).

In 2007, during sampling of Gua Dadeleang, a very muddy cave in Sulawesi, Indonesia, $8.7 \mathrm{~km}$ from the coast, nine specimens of a distinct, third species of Pseudohalmyrapseudes were collected.
Dadeleang Cave (referred to as Gua Deddelean 1 - SL1 in the report by Brouquisse 2002) comprises a main gallery about $50 \mathrm{~m}$ in length, with a mud floor, down the centre of which runs a small stream, one of the sources of the Sungai Salenrang on the western border of the Maros massif. There is a shallow pool outside the cave entrance held back by a small concrete dam. The gallery extends until a siphon is reached and within the gallery the stream widens into larger pools at intervals. There is a narrow, flooded gallery parallel to the main gallery. The tanaidaceans were collected in this parallel gallery. The new species is described below.

\section{MATERIAL AND METHODS}

Specimens were collected from the cave by Damia Jaume (IMEDEA, Mallorca, Spain) using a fine-mesh hand net and by capturing individuals from the surface water film on the mud using a paint brush. Material was examined using a Wild M3Z Kombistereo microscope and a Reichert Zetoplan compound microscope; drawings were made using a camera lucida. Measurements are axial, measured in dorsal aspect for the body, in lateral aspect for the appendages. Morphological terminology is as in Bamber and Sheader (2005), including the use of the term "segments" for serially repetitive body parts, notably those of the antennular and antennal flagella and uropod rami which are without independent musculature. The type material has been lodged at the Museum Zoologicum Bogoriense (MZB) and the Natural History Museum, London (NHM).

\section{SYSTEMATICS}

Suborder Apseudomorpha Sieg 1980

Superfamily Apseudoidea Leach 1814

Family Parapseudidae Gutu 1981 


\section{Genus Pseudohalmyrapseudes Larsen and} Hansknecht 2004

\section{Type species}

Pseudohalmyrapseudes aquadulcis Larsen and Hansknecht 2004, by original designation.

\section{Pseudohalmyrapseudes linnaei sp. nov.}

$$
\text { Figures 1-3 }
$$

\section{Material examined}

\section{Holotype}

Indonesia: Sulawesi: $q$ with oostegites, Gua Dadeleang, Kab. Pangkajene: co-ordinates of cave entrance: $4^{\circ} 55^{\prime} 33^{\prime \prime} \mathrm{S}, 119^{\circ} 36^{\prime} 36^{\prime \prime} \mathrm{E}$, 6 September 2007 , D. Jaume (MZB.Cru 1686).

\section{Paratypes}

Indonesia: Sulawesi: 1 subadult of (MZB.Cru 1687), 3 (MZB.Cru 1688), 3 (NHM.2007.964966), 1 q with oostegites, dissected, same sample as holotype.

\section{Description}

\section{Female}

Body (Figure 1A) elongate, poorly calcified, transparent in preserved material; holotype $5.8 \mathrm{~mm}$ long (tip of rostrum to posterior of pleotelson), nine times as long as wide. Cephalothorax slightly narrower anteriorly, as long as wide, with smoothly rounded rostrum; single lateral seta behind each ocular lobe, longer simple lateral seta anterior to each branchial chamber. Eyelobes present, rounded, eyes present as group of brown-pigmented ocelli. Epistome absent. Six free pereonites; pereonite 1 half as long as cephalon, pereonite 2 just shorter than pereonite 1, both with convex lateral margins; pereonites 3 to 5 subequal, 1.4 times as long as pereonite 1 , with midlateral indentation giving a bilobed outline; pereonite 6 as long as pereonite 1 , with bilobed outline (all pereonites respectively $1.9,1.6,1.15,1.15,1.0$ and 1.4 times as wide as long). All pereonites with sparse anterolateral and posterolateral simple setae. Pleon one third length of body, with five free subequal pleonites bearing pleopods; each pleonite about half as long as pereonite 6 and three times as wide as long, laterally extended into pointed epimera bearing 5 to 8 plumose setae, dorsally with sparse plumose setae. Pleotelson subrectangular, 0.7 times as long as all five pleonites together, 1.7 times as long as wide, with plumose lateral and dorsal setae.

Antennule (Figure 1B) proximal peduncle article 3.5 times as long as wide, with simple setae on inner and outer margins and penicillate setae in proximal half of outer margin; second peduncle article 0.4 times as long as first, some distal outer setae longer than article; third article half as long as second, with shorter inner and longer outer distal setae; fourth article 0.4 times as long as third, naked. Main flagellum of nine poorly distinguished segments, accessory flagellum of five segments.

Antenna (Figure $1 \mathrm{C}$ ) proximal peduncle article bearing rounded inner apophysis almost reaching distal margin of second article, with five outer setae; second article just shorter than first, bearing slender squama with three distal setae, smaller inner distal seta and longer seta at base of squama; third peduncle article one-third as long as second, with long inner distal seta; fourth and fifth articles as long as second, almost fused. Flagellum of four segments.

Labrum rounded, sparsely setose. Left mandible (Figure 1E) with four cusps on pars incisiva, four cusps on narrow lacinia mobilis, setiferous lobe with six compound setae, pars molaris round, blunt, with marginal setules; palp of three articles, proximal article with three long inner setae, second article longest, half as long as whole palp, with ten inner setae largely in two rows; third article with six progressively longer setae in distal half, distal setae longer than article. Right mandible as left but without lacinia mobilis, proximal palp article with four setae. Labium (Figure 1D) angular, outer marginal finely denticulate, inner margin setose, palp marginally setose and with single distal spine. Maxillule (Figure 1F) inner endite with four setose distal setae and outer apophysis, outer endite with 11 distal spines and setose margins; palp of two articles, distally with five simple setae. Maxilla damaged in preparation, with rostral row of 3 simple setae, fixed endite with trifurcate, simple and bifurcate setal groups. Maxilliped (Figure 1I) basis with three inner distal setae reaching distal margin of second palp article, outer distal corner finely denticulate; proximal palp article with simple outer strong seta, inner margin with single distal seta reaching distal margin of second palp article; second article with one strong distal seta on outer margin, inner margin with two rows of ten curved shorter setae, ventral row of four longer simple setae; third article with one distal and eight inner marginal simple setae; distal article with five simple inner-marginal and distal setae; endite (Figure $1 \mathrm{H}$ ) with simple, slender caudo-distal seta, simple distal spines, three coupling-hooks. Epignath (Figure 1G) large, rounded, setose inner lobe conspicuous, distal spine setose.

Cheliped (Figure 2A) with compact basis twice as long as wide, with long midventral seta exceeding distal tip of basis, five ventrodistal 


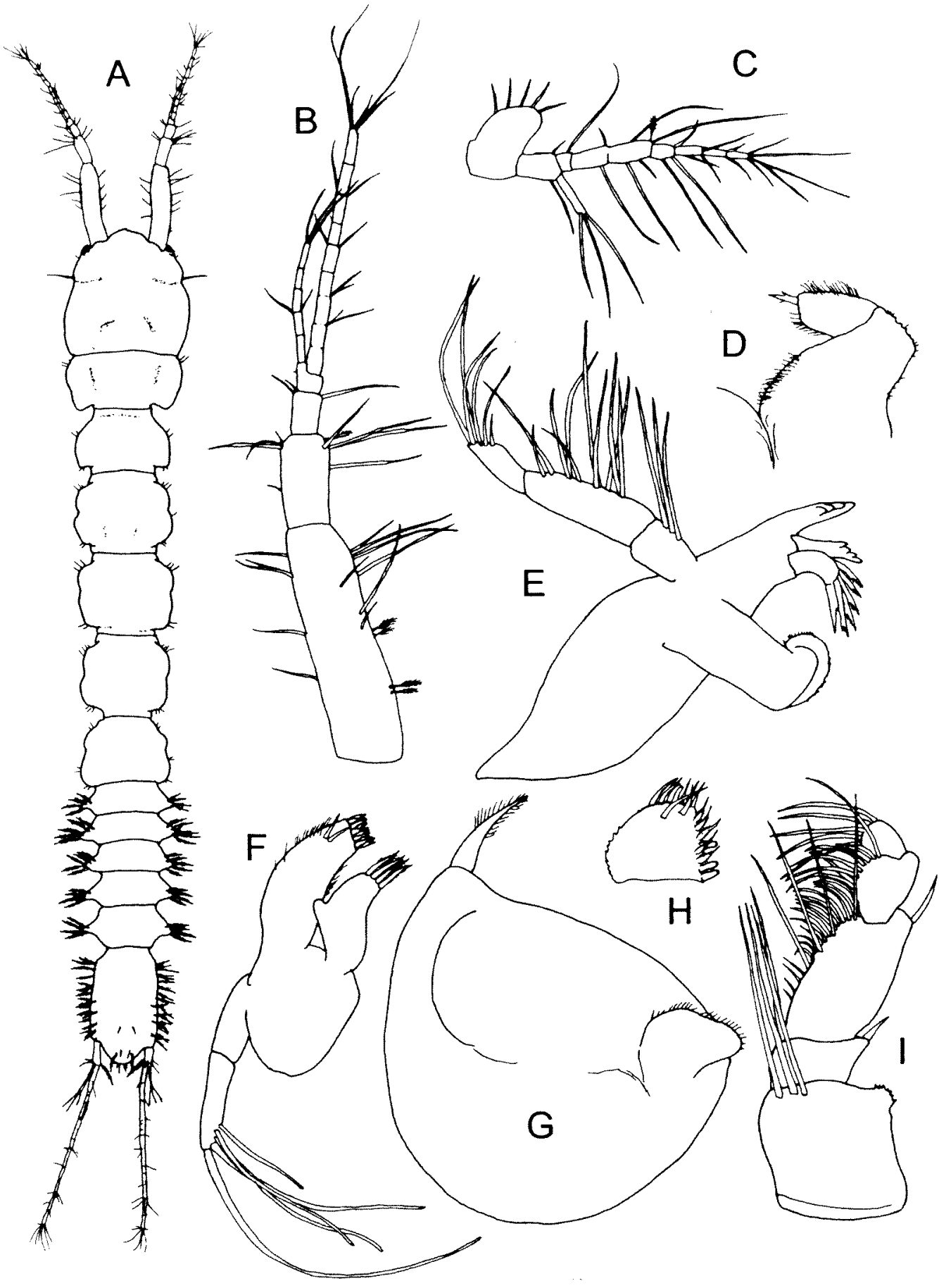

Figure 1 Psetutohalmyrapsendes limaei sp. nov, A, holotype, dorsal; B, antennule; C, antenna; D, labium; E, left mandible; F, maxillule; $G$, epignath; $H$, maxilliped endite; $I$, maxilliped. Scale line $=1.5 \mathrm{~mm}$ for $A, 0.4 \mathrm{~mm}$ for $B$ and $C$, $0.2 \mathrm{~mm}$ for $\mathrm{D}$ to $\mathrm{I}$.

setae; exopodite of three articles, distal article with four plumose setae. Merus subrectangular, ventrally with groups of three proximal and three distal setae, dorsally with single simple seta. Carpus elongate, 2.9 times as long as wide, with seven ventral marginal setae, outer mesial row of 14 simple setae, inner mesial row of eight simple setae. Propodus compact, setose as figured, fixed finger with four ventral setae, saw-like row of small, marginally spinulose teeth on cutting edge; moveable finger (dactylus), curved; unguis exceeding distal spine of fixed finger.

Pereopod 1 (Figure 2B) with stout basis 2.5 times as long as wide, dorsal margin bearing two small setae, ventral margin with three simple setae, ventrodistal tuft of five simple setae; exopodite of three articles, distal article with six plumose setae. Ischium short, with two ventrodistal setae. Merus 


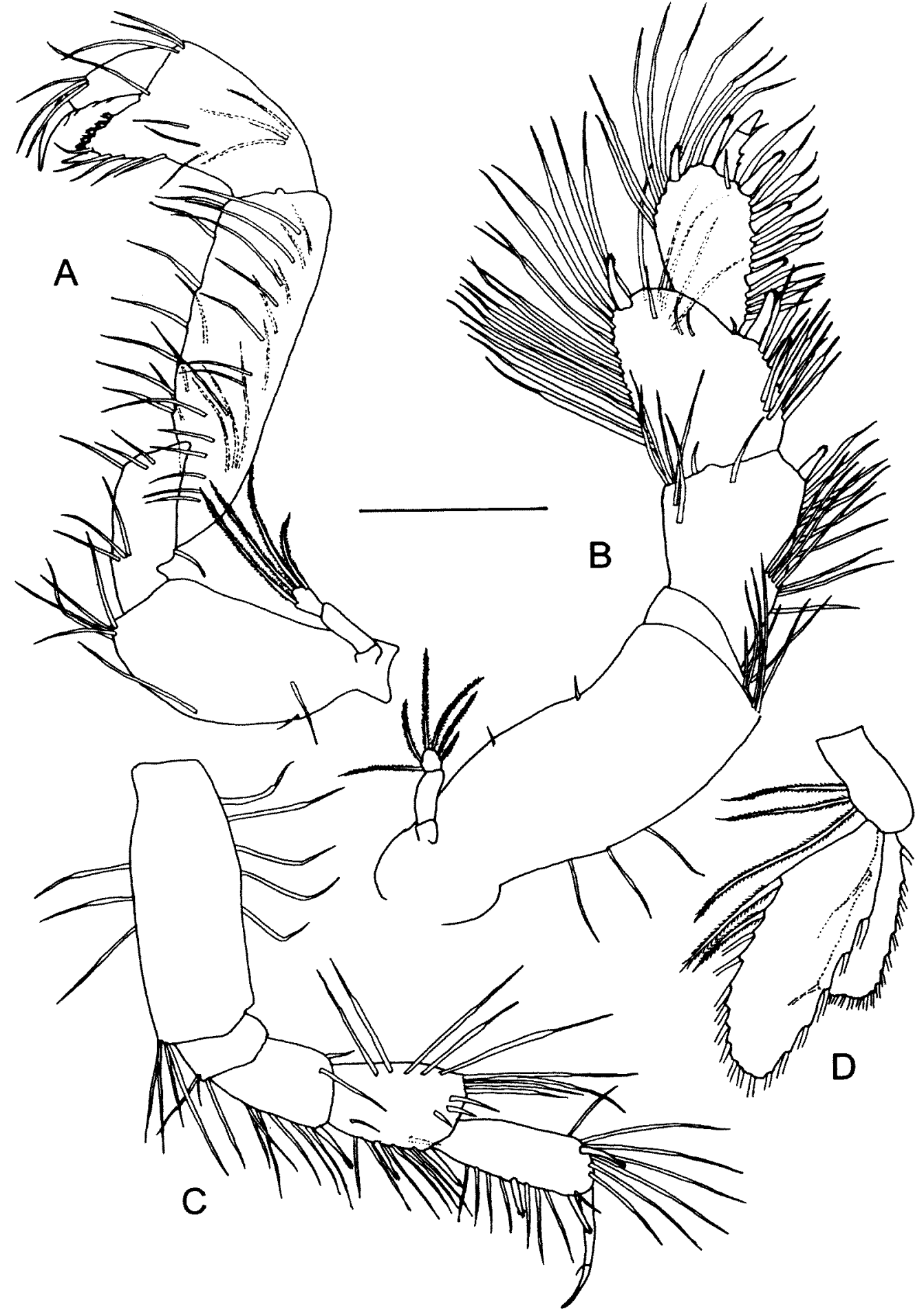

Figure 2 Pseudohalmyrapseudes linnaei sp. nov., A, cheliped; B, pereopod 1, C, pereopod 2; D, pleopod. Scale line = $0.3 \mathrm{~mm}$.

0.4 times as long as basis, dorsally with subdistal pair of longer, distally-tapering setae, distal tuft of three setae; ventral margin with numerous distally-tapering setae and ventrodistal spine. Carpus subequal in length to merus, numerous distally-tapering marginal spines dorsally and ventrally, one dorsodistal spine and two ventral spines. Propodus shorter than carpus, with three ventral and two dorsal spines, interspersed by distally-tapering setae. Dactylus curved, 0.3 times as long as propodus, with fine ventral denticulations and ventrodistal seta, unguis short, half as long as dactylus. All marginal spines with finely setulose tips.

Pereopod 2 (Figure 2C) basis compact, 2.6 times as long as wide, with five dorsal and three ventral marginal setae, and four simple ventrodistal setae; ischium with three ventrodistal setae. Merus, carpus and propodus bearing distally-tapering 


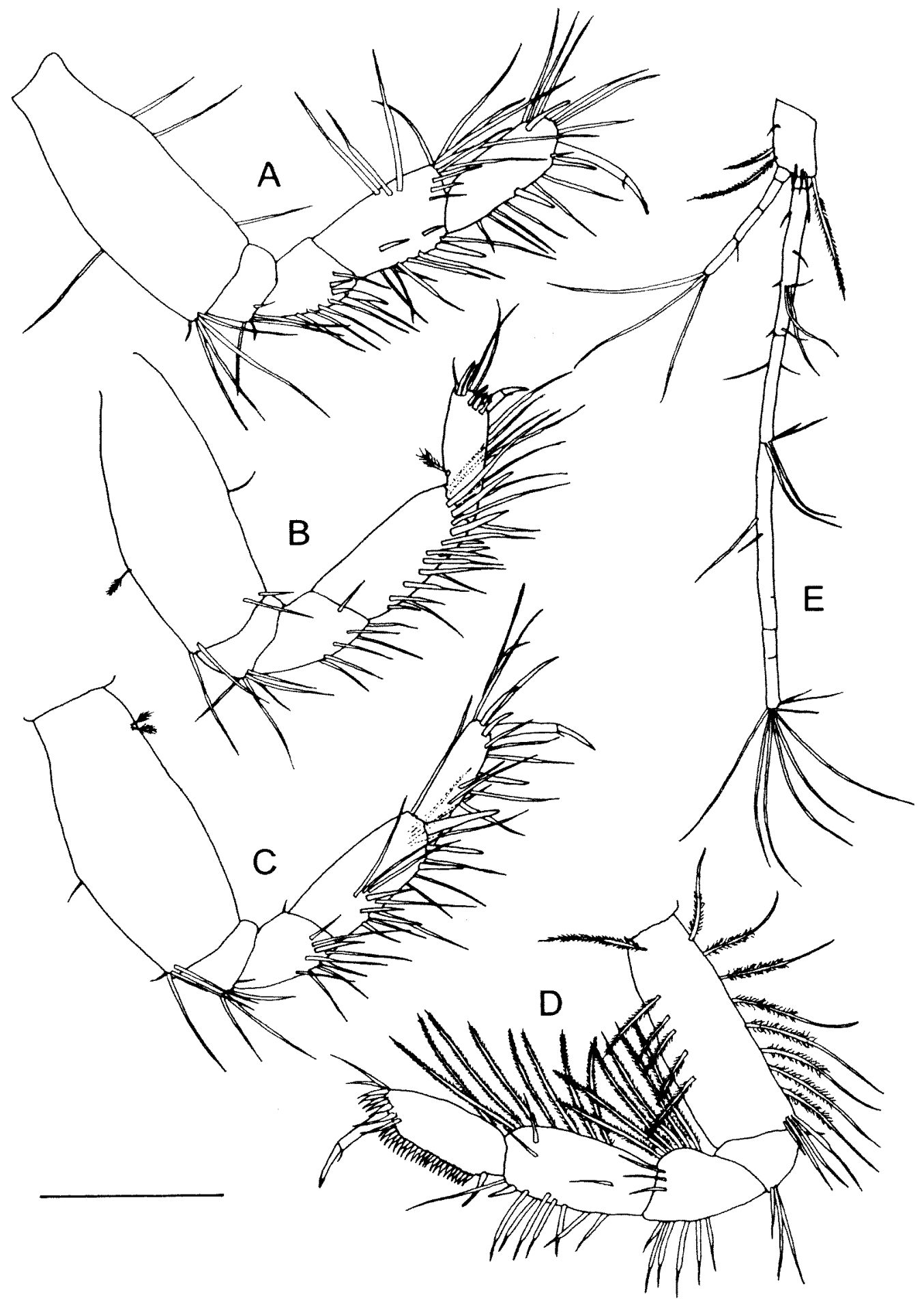

Figure 3 Pse'tdolnalmympsemtes limmei sp. nov, A, pereopod 3; B, pereopod 4; C, pereopod 5, D; pereopod 6; E, uropod. Scale line $=0.3 \mathrm{~mm}$.

setae. Merus 0.7 times as long as carpus, with slender ventrodistal spine; carpus with midventral and ventrodistal slender spines; propodus 1.2 times as long as carpus, with dorsodistal, midventral and ventrodistal slender spines; dactylus and unguis slender, together 0.8 times as long as propodus, dactylus with fine ventrodistal seta. Pereopod 3 (Figure $3 \mathrm{~A}$ ) similar to pereopod 2 , but with fewer setae on basis, merus 0.6 times as long as carpus.
Pereopod 4 (Figure 3B) basis with single dorsal marginal seta, midventral penicillate seta; carpus twice as long as merus, with distal crown of numerous tapering setae and slender spines; propodus with five denticulate distal spines; dactylus plus unguis 0.4 times as long as propodus, 0.4 times as long as dactylus plus claw of pereopods 3 or 5 .

Pereopod 5 (Figure 3C) similar to pereopod 3 , 


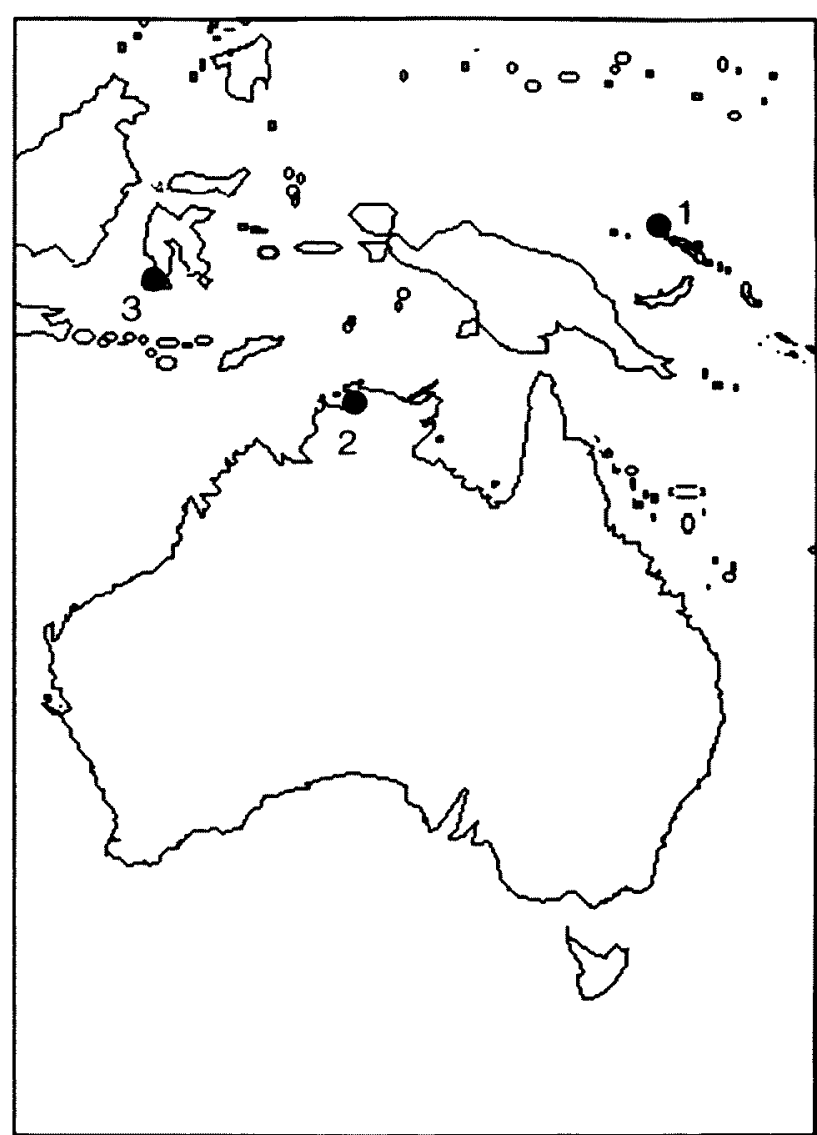

Figure 4 Distribution of known species of Pseudohalmyrapseudes: 1 - P. mussauensis; 2 P. aquadulcis; 3 - P. linnaei.

but basis sparsely setose. Pereopod 6 (Figure 3D) basis with six plumose dorsal setae, eight ventral marginal setae each plumose over its proximal half, and four distally-tapering ventrodistal setae; ischium dorsally naked; merus with six dorsal plumose setae, six ventral distally-tapering setae; carpus with eight dorsal plumose setae, small ventrodistal spine; propodus with proximal ventral slender spine, marginal row of 22 compound leaf-like spines, dactylus and unguis as pereopod 3 .

Pleopod (Figure 2D) biramous, basis with three dorsal plumose setae, ventral margin naked; exopod longer than endopod, outer proximal seta with trifurcate tip; endopod with single proximal outer seta; all setae plumose.

Uropod (Figure 3E) biramous, basis with two outer and one long inner distal plumose setae; endopod longer than basis, of one short and three longer segments; exopod showing poor segmentation, of perhaps nine or ten segments, longer than pleotelson and pleonite five combined.

Subadult male $2.8 \mathrm{~mm}$ long, similar to female, with penial tubercle ventrally on pereonite 6 . Paratype females 5.7 (female with oostegites), 4.8, $4.7,4.3,4.0,4.0$ and $3.9 \mathrm{~mm}$ long.

\section{Etymology}

This species is named in honour of Carolus Linneaus, in commemoration of the tercentenary of his birth and the 250th anniversary of the publication of the 10th edition of Systema Naturae.

\section{Remarks}

The three species of Pseudohalmyrapseudes are very similar to each other. Larsen and Hansknecht (2004) listed a number of differences between P. mussauensis and P. aquadulcis, which are expanded upon herein, although distinctions of the male are not feasible for the present species as the male of $P$. linnaei was not mature. The conspicuous difference between the three species is the shape of the inner apophysis of the proximal antennal peduncle article, that of $P$. mussauensis being triangular, exceeding the distal margin of the second peduncle article, and with outer and distal marginal setae; the apophysis of $P$. aquadulcis is rectangular, not quite reaching the distal margin of the second peduncle article, with distal setae on the straight apex; the apophysis of $P$. linnaei is rounded, again not quite reaching the distal margin of the second peduncle article, with setae evenly dispersed around the outer margin. The third antennal article is much shorter proportionately in $P$. linnaei, although it may have been present but unobserved in $P$. aquadulcis, otherwise it is difficult to interpret the inevitable five peduncle articles. The poor articulation between articles 4 and 5 of the antenna in $P$. linnaei, in contrast with the clear articulation in the other species, was present in all specimens (as was also the case for the antennule main flagellum and uropod endopod). The conformation of the epignath appears to be quite distinct between the three species, that of $P$. linnaei being almost circular, that of $P$. mussauensis being oval, while that of $P$. aquadulcis is unusually elongate, and without setae on either the inner lobe or the distal spine. Finally, $P$. linnaei has plumose pleonite setae restricted to the lateral epimera, while there are almost none on the dorsal surface of the pleotelson, while in both of the other species these setae extend onto the dorsal surfaces of the pleonites and are numerous on the dorsal surface of the pleotelson.

A range of other differences between the three species is shown in Table 1. Pseudohalmyrapseudes aquadulcis is distinct from the other two species in having 4 segments in the antennule accessory flagellum ( 5 in the other two), only two setae on the proximal article of the mandibular palp ( 3 or 4 in the other two), apparently no distal spine on the labial palp ( 1 in P. linnaei, 2 in $P$. mussauensis), only 4 plumose setae on the exopod of pereopod 1 ( 6 in the other two), a plumose seta on the ischium of pereopod 6 (none in the other 
Table 1 Distinctions between the three described species of Psetudolatmlrapsedtes

\begin{tabular}{|c|c|c|c|}
\hline & P. linnaci & P. aquadulcis & P. mussauensis \\
\hline Pleotelson length v pleonites 1-5 length & $0.7 \times$ & $>0.75$ & $<0.6$ \\
\hline Antennule accessory flagellum, female & 5 segments & 4 segments & 5 segments \\
\hline Antenna apophysis on proximal article & $\begin{array}{l}\text { Round, setae } \\
\text { evenly marginal }\end{array}$ & $\begin{array}{c}\text { Rectangular, setae } \\
\text { distal on straight apex }\end{array}$ & $\begin{array}{l}\text { Triangular, setae } \\
\text { evenly marginal }\end{array}$ \\
\hline Maxilliped basis outer-distal corner & Denticulate & Denticulate & Smooth \\
\hline Maxilliped basis distal setae & 3 & 3 & 2 \\
\hline Dactylus + unguis pereopod 4 & $\begin{array}{c}0.4 \times \text { length of those } \\
\text { of } \mathrm{P3} \text { and } \mathrm{P5}\end{array}$ & $\begin{array}{c}0.4 \times \text { length of those } \\
\text { of } P 3 \text { and } P 5\end{array}$ & $\begin{array}{c}>0.5 \text { length of those } \\
\text { of } \mathrm{P3} \text { and } \mathrm{P5}\end{array}$ \\
\hline Cephalothorax length: width & 1.0 & 1.1 & 1.2 \\
\hline Mandible palp, setae on proximal article & 3 or 4 & 2 & 3 \\
\hline Labial palp distal spines & 1 & 0 & 2 \\
\hline Epignath & Round; setose & Elongate; naked & Oval; setose \\
\hline Pereopod 1, distal exopod article setae & 6 & 4 & 6 \\
\hline Pereopod 1 dactylus & Denticulate & Not denticulate & Denticulate \\
\hline Pereopod 6 , ischium plumose setae & 0 & 1 & 0 \\
\hline Pleopod endopod outer margin & 1 proximal seta & Naked & Naked \\
\hline Uropod basis plumose setae & 3 & 1 & 5 \\
\hline
\end{tabular}

two), no denticulation on the dactylus of pereopod 1 (denticulate in the other two) and only one plumose distal seta on the uropod basis ( 3 or more in the other two species). Larsen and Hansknecht (2004) describe only nine distal spines on the outer endite of the maxillule, but this is likely to be a miscount, both of the other species having 11 .

As well as the dorsal pleon setation, and antennule and epignath features, $P$. linnaci differs from $P$. mussauensis in having a denticulate outer-distal corner to the maxilliped basis (smooth in $P$. mussauensis), three distal setae on the maxilliped basis (2), one distal spine on the labial palp (2), and a proximal seta on the pleopod endopod outer margin (naked in both of the other species). P. mussauensis has a proportionately shorter pleotelson, and a proportionately longer cephalothorax. I believe that the short proximal segment of the uropod exopod of $P$. mussauensis was missed by Shiino (1965), and thus it too was of four segments, as in the other two species.

\section{DISCUSSION}

This group of closely-related species shows inevitable reproductive isolation, owing to its restriction to sites of freshwater habitat separated by extensive areas of fully-marine sea-water, which would be expected to lead to genetic drift and allopatric speciation. A range of subtle if consistent distinctions in a generally conservative morphology is thus not surprising as an expression of this evolution.

The genus remains distributed around the Australasian region (Figure 4), $P$. linnaci from southwestern Sulawesi, off the Flores Sea, $P$. aquadulcis further south from near Darwin, Australia, off the Timor Sea, and P. mussauensis further east from Mussau Island in the northern Melanesian waters of the Bismarck Archipelago. It is to be expected that further species may be present isolated on other islands of this region.

The closely-related genus Halmyrapseudes shows a different zoogeography (Bamber et al. 2002), three of the known species being found in the Caribbean and Gulf of Mexico, the other four occurring around the Indian Ocean. Soemodinoto ef al. (1995) recorded large numbers of a species attributed to $H$. killaiyensis Balasubrahmanyan 1959 from an estuary in Java, although that material has been lost (A. Soemodinoto, pers. comm.): rediscovery of this taxon would be valuable as a putative link between these two genera. The tanaidacean fauna of the Indonesian region is conspicuously understudied.

\section{ACKNOWLEDGEMENTS}

Thanks are due to Damia Jaume (IMEDEA) for collecting the material. Sampling in Sulawesi was conducted during an international expedition, Zoological meestigations in the Karsts of South and Southeast Sulawesi, organized by Dr Louis Deharveng of the Museum national d'Histoire naturelle, Paris in collaboration with Dr Yayuk Suhardjono and Cahyo Rahmadi of the Lembaga IImu Pengethuan Indonesia (LIPI - the Indonesian Institute of Sciences). The expedition operated under research permits granted by LIPI. The specimens were gathered during fieldwork carried out by the aquatic team of Damia Jaume, Geoff 
Boxshall (NHM) and Daisy Wowor (Museum Zoologicum Bogoriense). The support of the fieldwork by the Percy Sladen Memorial Fund (administered by the Linnean Society of London) is gratefully acknowledged.

\section{REFERENCES}

Bãcescu, M. and Gutu, M. (1974). Halmyrapseudes cubanensis n.g.n.sp. and H. bahamensis n.sp., brackish water species of Tanaidacea (Crustacea). Traonux du Museum d'Histoire naturelle "Grigore Antipa" 15 : 91-101.

Bamber, R.N., Ariyananda, T. and Silva, E.I.L. (2002). The male of Halmyrapseudes srilankaensis (Bãcescu, 1981) comb. nov. and an analysis of the genus Halmyrapseudes Bãcescu and Gutu, 1974 (Peracarida, Tanaidacea). Journal of Crustacean Biology 22: 287-297.

Bamber, R. N. and Sheader, M. (2005). Apseudomorph Tanaidacea (Crustacea: Malacostraca: Peracarida) from shallow waters off Sabah, Malaysia. Systematics and Biodiversity 2: 281-303.

Brouquisse, F. (2002). Expédition Maros 99 - Rapport spéléologique. Association Pyrénéenne de Spéléologie, Toulouse. $39 \mathrm{pp}$.

Gardiner, L. F. (1975). A fresh- and brackish-water tanaidacean, Tanais stanfordi Richardson, 1901, from a hypersaline lake in the Galapagos Archipelago, with a report on West Indian specimens. Crustaceana 29 (2): $127-140$.

Gutu, M. (1981). A new contribution to the systematics and phylogeny of the suborder Monokonophora (Crustacea, Tanaidacea). Travaux du Muséum National d'Histoire Naturelle "Grigore Antipa" 23: 81-108.

Krøyer, H. (1842). Nye Arter af Slægten Tanais. Naturhistorishe Tiddskrift 4: 167-188.
Larsen, K. and Hansknecht, T. (2004). A new genus and species of freshwater tanaidacean, Pseudohalmyrapseudes aquadulcis (Apseudomorpha: Parapseudidae), from Northern Territory, Australia. Journal of Crustacean Biology 24: 567-575.

Leach, W.E. (1814). Crustaceology. In: Brewster, D., The Edinburgh Encyclopaedia: 383-437. Edinburgh.

Monod, T. (1977). La faune terrestre de l'ile de SainteHelene. Quatrieme partie. 5. Tanaidacea. Annales $d u$ Musé Royal de l'Afrique Centrale. Terouren, Belgique Annales. Série in $8^{\circ}$. Sciences Zoologiques 220: 457-465.

Richardson, H. (1901). Papers from the Hopkins Stanford Galapagos Expedition, 1898-1899. VI. The isopods. Proceedings of the Washington Academy of Sciences 3: 565-568.

Shiino, S. M. (1965). Tanaidacea from the Bismarck Archipelago. Videnskabelige Meddeleiser fra Dansk Naturhistorisk Forening i Kjabenhavn 128: 177-203.

Sieg, J. (1980). Sind die Dikonophora eine polyphyletische Gruppe? Zoologischer Anzieger 205: 401-416.

Soemodinoto, A., Oey, B. L. and Ibkar-Kramadibrata, H. (1995). Effect of salinity decline on macrozoobenthos community of Cibeureum river estuary, Java, Indonesia. Indian Journal of Marine Sciences 24: 62-67.

Stephensen, K. (1936). A tanaid (Tanais stanfordi Richardson) found in freshwater in the Kurile Islands, with taxonomic remarks on the genus Tanais sensu lat. (Tanais Audouin et Milne-Edwards 1829, and Anatanais Nordenstam 1930). Annotationes Zoologicae Japonenses 15 (3): 361-373.

Van Name, W. G. (1925). The isopods of Kartabo Bartica District, British Guiana. Zoologica (New York) 6: 461503.

Manuscript received 1 April 2008; accepted 6 May 2008. 